\title{
Characterization and Control of Garlic Rust in California
}

Steven T. Koike and Richard F. Smith, University of California Cooperative Extension, Salinas 93901; R. Michael Davis, Department of Plant Pathology, University of California, Davis 95616; J. Joe Nunez, University of California Cooperative Extension, Bakersfield 93307; and Ron E. Voss, Department of Vegetable Crops, University of California, Davis 95616

\begin{abstract}
Koike, S. T., Smith, R. F., Davis, R. M., Nunez, J. J., and Voss, R. E. 2001. Characterization and control of garlic rust in California. Plant Dis. 85:585-591.

In 1998, a devastating outbreak of rust disease severely damaged the garlic crop in California, resulting in yield losses of $51 \%$ and an economic loss of $27 \%$ to the industry. The disease also occurred in 1999 and 2000, indicating that rust may have become an annual problem in some parts of the state. The presence of urediniospores, two-celled teliospores, and telial paraphyses indicated that the pathogen was Puccinia allii. Isolates from garlic infected onion and chives, but not leek, elephant garlic, or shallot in inoculation experiments. Garlic cloves obtained from diseased plants were planted under controlled conditions, but the resulting plants did not develop rust. Fungicide trials were conducted for 3 years and showed that none of the currently registered materials gave satisfactory control. However, tebuconazole and azoxystrobin provided good protection against rust if sprayed at 10-day intervals. A variety trial of 34 garlic cultivars and selections was planted, inoculated, and evaluated for resistance to rust. Although there was variability in rust severity among the selections, acceptable levels of resistance were not observed in any cultivar.
\end{abstract}

Additional keywords: Allium cepa, Allium porrum, Allium sativum

Approximately $84 \%$ of the U.S. commercial garlic (Allium sativum L.) acreage is produced in California (6). Typical yields are in the range of 20,730 (1997) to 22,360 (1999) kg/ha (Table 1). Roughly 60 to $65 \%$ of the total acreage is grown for dehydrated products, while the balance is destined for fresh market. Commercial garlic in California is divided into early (planted early to late October) and late (planted late October to early December) crops that are harvested in mid-June to early July and late July, respectively. Most of the state's garlic is grown in the inland San Joaquin Valley (Fresno and Kern counties) and the coastal Salinas Valley (Monterey County). Garlic crops in California are usually subject to only a few foliar diseases, including purple blotch caused by Stemphylium vesicarium and diseases caused by Botrytis spp. (28).

In 1998, a devastating outbreak of rust disease affected garlic throughout California. During this year, California experienced El Niño weather conditions, with record high rainfall and long periods of cool temperatures. The disease was particularly damaging in central coast

Corresponding author: S. T. Koike

E-mail: stkoike@ucdavis.edu

Accepted for publication 12 February 2001

Publication no. D-2001-0321-02R

(C) 2001 The American Phytopathological Society
(Monterey, San Benito, Santa Clara) and San Joaquin Valley (Fresno, Kern, Kings) counties. Disease was widespread, and in many fields $100 \%$ of the plants were infected. An estimated $54 \%$ of the California acreage $(8,100$ ha) was affected with rust (S. T. Koike, unpublished; E. A. Kurtz, personal communication). Early symptoms consisted of small $(<2 \mathrm{~mm})$, circular to elongate, white flecks that occurred on both sides of leaves. As disease progressed, these small spots expanded into oblong lesions. The leaf tissue covering the lesions ruptured, and masses of the characteristic orange urediniospores became visible as pustules. Severely infected leaves were almost entirely covered with pustules, resulting in extensive yellowing, wilting, and drying of leaves. Teliospores later developed on the same leaves, resulting in black pustules. Uredia and telia were both amphigenous. The severity of the rust caused entire fields to turn prematurely yellow and then brown.

While rust on California garlic was reported in the literature as early as 1940 (14), the disease has never been known to be an important economic problem. This serious outbreak was therefore an unprecedented event for California and had significant impacts on yields. Harvested bulbs were significantly smaller than normal, and bulb weights were reduced from 25 to $60 \%$ of normal. In addition, the quality of the crop was severely reduced. Soluble solids were reduced $15 \%$, and affected bulbs lacked the protective dry outer skins, which caused the bulbs to shatter if harvested mechanically. Growers were therefore forced to use hand labor to retrieve the bulbs, causing harvest costs to be three to five times higher than usual. Average yields in 1998 were reduced $51 \%$ from typical state production levels, and the crop value per hectare for this season was reduced $27 \%$ compared with more typical years such as 1997 and 1999 (Table 1).

The objectives of this study were to characterize the pathogen, investigate the host range and possible inoculum source of the fungus, and evaluate fungicides and garlic cultivars for rust prevention and control. A preliminary report has been published (22).

\section{MATERIALS AND METHODS}

Characterization of the pathogen. To identify the species of the rust pathogen, samples of diseased garlic and onion were collected from various locations in California. Garlic samples were collected in 1998 and 1999 from the following coastal locations: Soledad, three fields; King City, four fields; and Hollister, two fields. Two garlic samples were collected from the inland San Joaquin Valley: Bakersfield (two fields). One rust-infected onion sam-

Table 1. California garlic production for 1997 to $1999^{y}$

\begin{tabular}{lccc}
\hline Year & Area $(\mathbf{h a})$ & Yield $\mathbf{( k g / h a )}$ & $\begin{array}{c}\text { Gross value/area } \\
\mathbf{( \$ / h a )}\end{array}$ \\
\hline 1997 & 11,992 & 20,731 & 10,473 \\
$1998^{\mathrm{z}}$ & 15,140 & 10,534 & 7,943 \\
1999 & 15,985 & 22,357 & 11,356 \\
1997 and 1999 mean & & 21,544 & 10,915 \\
1998 figure as a percentage & & $49 \%$ & $73 \%$ \\
$\quad$ of 1997/1999 mean & &
\end{tabular}

y Statistics are from California Agricultural Statistics Service: County Agricultural Commissioners' Data (6).

${ }^{\mathrm{z}}$ Severe garlic rust outbreak occurred in 1998. 
ple was obtained from Salinas (one field). For each field sample, 50 spores from each of four leaves were measured and a range of dimensions was determined for each location. Urediniospore dimensions were determined by placing spores in a drop of water on a glass slide and examining them with a microscope. Germ pores in urediniospores were observed using the method of Jennings et al. (17) by transferring spores to a drop of aniline blue dissolved in lactic acid $(0.1 \% \mathrm{wt} / \mathrm{vol})$ that was placed on a glass slide. The underside of the slide was gently heated until the solution began to emit vapors. A coverslip was placed on top of the drop and firmly pressed to squash the urediniospores. The slide was then examined with a microscope with phase contrast. Telial structures and teliospore dimensions were determined by using a razor blade to make thin slices through telia in leaf tissue. Telial slices were mounted in a drop of water and examined with a microscope.

Host range of the pathogen. To determine the range of Allium plants susceptible to the California garlic rust pathogen, rust isolates were collected from three locations (Soledad, King City, and Hollister) in California by harvesting severely diseased garlic leaves from commercial fields. For each isolate, $5-\mathrm{cm}$ sections of garlic leaves were agitated in sterile distilled water for $30 \mathrm{~min}$. The resulting suspension was filtered through one layer of cheesecloth, adjusted to approximately $1 \times 10^{7}$ urediniospores per $\mathrm{ml}$, and then sprayed until runoff onto 10 2-month-old plants of the following Allium species: garlic cvs. California Late and Chinese Early Red; onion (A. cepa L.) cvs. Yula, Southport White, Stockton Early Yellow, and Early Red Burger; chives (A. schoenoprasum L.) cv. Fine Leaved; leek (A. porrum L. [=A. ampeloprasum var. porrum (L.) Gay]) cvs. Titan, Broad London, and Gavilan; elephant garlic (A. ampeloprasum L.); and shallot (A. cepa var. ascalonicum L.) cvs. Ambition, Atlas, and Creation. Immediately after inoculation, plants were placed for $48 \mathrm{~h}$ in a dew chamber that maintained constant leaf wetness at 18 to $19^{\circ} \mathrm{C}$, then subsequently grown in a greenhouse at 22 to $24^{\circ} \mathrm{C}$. After 8 weeks, the severity of infection was estimated using a rust severity scale where $0=0 \%, 1=1$ to $10 \%, 2=$ 11 to $25 \%, 3=26$ to $50 \%, 4=51$ to $75 \%$, and $5=76$ to $100 \%$ of the leaf surface covered with lesions. Values presented are the means of 10 plants. This inoculation experiment was repeated once.

Garlic seed as source of rust inoculum. Because garlic is planted in the field in the form of cloves ("garlic seed"), we designed an experiment to determine if diseased or contaminated garlic seed could be a source of initial inoculum for rust. Bulbs were collected from mature plants that were part of a completed fungicide trial. Treatments, therefore, consisted of bulbs that developed from severely diseased (untreated) or lightly to moderately diseased plants (sprayed with propiconazole, tebuconazole, maneb, or azoxystrobin). For each treatment, bulbs were cracked open, and the resulting cloves, including the attached dry sheaths, were planted into trays containing a soilless peat moss mix. Approximately 50 cloves were planted in each of four replicate trays. Trays were placed in dew chambers each night and were maintained in an enclosed greenhouse during the day. The greenhouse was free from garlic and other Allium plants, and was not located near onion or garlic fields, so contaminating rust spores would be excluded. After clove germination, plants were examined weekly for symptoms and signs of rust. The experiment was conducted twice.

Field evaluations of fungicides. Field evaluations of fungicides for control of rust were conducted in three commercial fields in 1998 (two in San Benito County and one in Kern County) and in two fields in 1999 (Monterey County). In 1998, trials were conducted in fields already exhibiting signs and symptoms of the disease. Site 1998A (San Benito County) included the following treatments and rates per hectare: untreated control; propiconazole (Tilt 3.6E), 0.59 liter; myclobutanil (Rally 40W), 0.28 $\mathrm{kg}$; azoxystrobin (Quadris 2.08SC), 1.13 liter; chlorothalonil (Bravo Weather Stik 6F), 2.34 liter; iprodione (Rovral 4F), 1.75 liter; tebuconazole (Folicur 3.6F), 0.59 liter; and maneb (Maneb $75 \mathrm{DF}), 3.37 \mathrm{~kg}$. Site 1998B (San Benito County) included: untreated control; mancozeb (Manzate 200), $3.37 \mathrm{~kg}$; tebuconazole (Folicur 3.6F), 0.59 liter; azoxystrobin (Quadris 2.08SC), 1.13 liter; chlorothalonil (Bravo Weather Stik 6F), 2.34 liter; and chlorothalonil (2.34 liter) + mancozeb (3.37 kg). In Kern County (site 1998C), treatments included: untreated control; metalaxyl-mancozeb (Ridomil MZ), $2.80 \mathrm{~kg}$; chlorothalonil (Bravo 720), $2.50 \mathrm{~kg}$; sulfur (Thiolux), $11.20 \mathrm{~kg}$; copper hydroxide (Kocide DF), $1.40 \mathrm{~kg}$; and maneb (Manex), $2.70 \mathrm{~kg}$. All fungicides were applied four times at 7 - to 10-day intervals, with the exception of the Kern County site, in which the fourth application was made 14 days after the previous one.

Trials in 1999 were initiated before rust occurrence, and treatments received either four (at 10-day intervals) or two (at 20-day intervals) sprays. One experiment was conducted in a commercial field and the other at the Hartnell College East Campus. To provide inoculum at the Hartnell site, in January 1999, dried garlic leaves that were infected by rust and collected the previous fall were spread on the ground between the plant rows at the rate of $1.80 \mathrm{~kg}$ per $6 \mathrm{~m}$ by two bed plot. Plots in commercial fields relied on natural inoculum. Treatments and rates per hectare applied at 10 - or 20-day intervals at both sites were: untreated con- trol; tebuconazole (Folicur 3.6F) at 0.59 or 0.44 liter; azoxystrobin (Quadris 2.08SC) at 1.13 or 0.80 liter; mancozeb (Manzate 200 ) at $3.37 \mathrm{~kg}$; and benzothiadiazole (Actigard) at $0.07 \mathrm{~kg}$.

For all trials, experimental designs were randomized complete blocks with four replications. For all sites except Kern County, plots measured $6 \mathrm{~m}$ long by two beds wide (each bed was $1 \mathrm{~m}$ wide) and contained two garlic seed rows per bed. Treatments were applied in 840 liters of water per hectare using a $\mathrm{CO}_{2}$ backpack sprayer pressurized to $241 \mathrm{kPa}$, a 4-nozzle hand-held boom (48-cm spacing between nozzles), and Teejet 8005 flat fan nozzles. A nonionic surfactant (Hook; $0.3 \mathrm{ml} /$ liter of final spray mixture) was added to all sprays. In the Kern County site, each plot measured $4.6 \mathrm{~m}$ long by three beds wide (each bed was $1 \mathrm{~m}$ wide) and contained two garlic seed rows per bed. Treatments were applied in 337 liters of water per ha using a $\mathrm{CO}_{2}$ backpack sprayer pressurized to $241 \mathrm{kPa}$, a 3-nozzle hand-held boom (34 $\mathrm{cm}$ spacing between nozzles), and Teejet 8002 flat fan nozzles.

Near crop maturity but before the last irrigation, rust severity at sites 1998A, 1998B, 1999A, and 1999B was evaluated on the third, fourth, and fifth youngest leaves by using the severity scale described previously. As an additional measurement of rust impact, the total number of viable leaves per plant (viable $=$ more than $75 \%$ of the leaf area is healthy) was counted. Eight plants per plot were evaluated, and a mean value was derived for each plot. Plot yields were determined by harvesting garlic from a 3-m length of the middle two rows of each plot. Harvested bulbs were trimmed according to standard commercial practice and weighed. Two cloves from each of 10 bulbs were pressed in a garlic press and the resulting juice evaluated for percent soluble solids using a temperature compensating refractometer. A mean value was derived for each set of 20 cloves.

For site 1998C, treatment effects were assessed on plants in a 1-m length of row from the center bed of each plot. Because of the severe disease that occurred at this location, only the youngest leaves could be evaluated. Fifteen of the youngest leaves per plot were randomly sampled and rated for percent leaf surface covered with lesions. These leaves were then oven-dried at $45^{\circ} \mathrm{C}$ for 7 days and the resulting dry weights recorded. Garlic bulbs were harvested from a 1-m length of row in the center bed of each plot, trimmed, counted, and weighed. Mean bulb weight was then calculated.

Cultivar evaluation. To evaluate various garlic cultivars and breeding lines for resistance to rust, a field trial was planted in Monterey County in November 1999. The experimental design was a randomized complete block with five replications and 34 garlic varieties and selections. Each plot 
measured $3 \mathrm{~m}$ long by one bed wide $(1 \mathrm{~m})$ and contained two garlic seed rows per bed. To provide inoculum, dried garlic leaves that were infected by rust and collected the previous fall were spread on the ground in February 2000 between the plant rows at the rate of $450 \mathrm{~g}$ per each one-bed by $3-\mathrm{m}$ plot. The plots were sprinkle irrigated and grown according to commercial practices. On 7 April 2000, plots were evaluated for disease severity and number of viable leaves as described previously. Vigor and maturity evaluations were made on 1 May.

Statistical analyses. For all inoculation and fungicide experiments, analyses of variance and least significant differences (LSD) were calculated using the MSTATC (Michigan State University, East Lansing) statistical program. For the cultivar trial, analysis of variance and LSD were calculated using the Statgraphics statistical program.

\section{RESULTS}

Characterization of the pathogen. Urediniospores from all locations and years were similar and were spherical to ellipsoidal, echinulate, orange colored in mass, and had a range of dimensions of 28 to $31 \mu \mathrm{m} \times 25$ to $28 \mu \mathrm{m}$ (Table 2). Germ pores numbered 7 to 10 per urediniospore and were in a scattered arrangement. Telia and teliospores from all locations and years were likewise similar. Telia were black, remained covered by intact epidermis tissue, and contained fused paraphyses that were arranged so that locules were formed within the telia. Teliospores were located within telial locules and were brown, smooth walled, two-celled, and had a range of dimensions of 42 to $53 \mu \mathrm{m} \times 17$ to 22 $\mu \mathrm{m}$ (Table 2). Apical cells had acute or obtuse tops and were darker and smaller than the lower cells. Teliospore pedicels were hyaline, fragile, and often broken, and relatively short in length (3 to $17 \mu \mathrm{m})$. One-celled spores (mesospores) were rare. Pycnia and aecia were not observed on any garlic rust samples. Based on the characteristics of urediniospores, teliospores, and telia, the pathogen causing rust in California was confirmed to be Puccinia allii (DC.) Rud., an autoecious rust pathogen infecting plants in the genus Allium.

Allium host range of the pathogen. Light to moderate rust developed on all inoculated garlic plants of both cultivars after 4 to 5 weeks (Table 3 ). All four onion cultivars were susceptible to the $P$. allii isolates from garlic. However, disease severity on onion was consistently lower than on garlic. The chives cultivar was susceptible. Two shallot cultivars (Ambition and Creation) were uninfected, and the third cultivar (Creation) had a total of only two small pustules on all leaves from all plants. Leek and elephant garlic plants failed to develop any symptoms or signs of rust (Table 3). There were no significant differences $(P<0.05)$ in virulence among the Soledad, King City, and Hollister isolates, and results from the two experiments were similar.

Garlic seed as source of rust inoculum. After 5 months of growth in a greenhouse, none of the garlic seed plantings developed rust. Plants that grew from untreated or fungicide-treated cloves failed to show any symptoms or signs of garlic rust. The results were the same for both experiments.

Field evaluation of fungicides. In the San Benito trials (1998A and 1998B), tebuconazole, propiconazole, and azoxystrobin treatments consistently resulted in the lowest severity ratings and highest number of viable leaves (Table 4). Relative to the other treatments, tebuconazole and azoxystrobin resulted in the highest yields and percent soluble solids (Table 4). At site 1998A, propiconazole was the only other fungicide that resulted in harvest weights that were significantly higher than those of the untreated controls.

In Kern County (1998C), none of the materials, all of which were registered on garlic, provided adequate control (Table 5). Slight differences occurred in the percent leaf infection, dry weight of foliage, and average weight of bulbs $(P=0.10)$. Metalaxyl-mancozeb, maneb, and chlorothalonil provided the greatest amount of control.

In the $1999 \mathrm{~A}$ and $\mathrm{B}$ trials, results were similar at both locations and the data were combined for analysis (Table 6). If sprayed at 10-day intervals, tebuconazole and azoxystrobin treatments at either high or low rates gave excellent rust control; such control was significantly better than untreated controls and all other fungicide treatments. Most treatments resulted in significantly higher numbers of viable

Table 2. Morphological characteristics of Puccinia allii isolates from garlic and onion in California

\begin{tabular}{|c|c|c|c|c|c|c|}
\hline \multirow[b]{3}{*}{ Structures } & \multicolumn{6}{|c|}{ Isolate measurements $(\mu \mathrm{m})^{\mathrm{x}}$} \\
\hline & \multicolumn{4}{|c|}{ Garlic } & \multirow{2}{*}{$\begin{array}{l}\text { Onion } \\
\text { Salinas } \\
\end{array}$} & \multirow{2}{*}{$\begin{array}{c}\text { Published } \\
\text { values }^{\mathrm{z}}\end{array}$} \\
\hline & Soledad & King City & Hollister & Bakersfield & & \\
\hline \multicolumn{7}{|l|}{ Urediniospores } \\
\hline Length & $28-31$ & $28-31$ & $25-31$ & $28-31$ & $28-31$ & $23-32$ \\
\hline Width & $25-28$ & $28-31$ & $25-28$ & $25-28$ & $25-31$ & $20-26$ \\
\hline \multicolumn{7}{|l|}{ Teliospores } \\
\hline Length, total & $42-53$ & $39-53$ & $42-53$ & $42-56$ & $\ldots$ & $36-65$ \\
\hline Length, top cell & $17-22$ & $19-25$ & $19-25$ & $17-25$ & $\ldots$ & $\ldots$ \\
\hline Length, bottom & $25-31$ & $20-28$ & $23-28$ & $25-31$ & $\ldots$ & $\ldots$ \\
\hline Width & $17-19$ & $17-19$ & $17-22$ & $17-25$ & $\ldots$ & $18-28$ \\
\hline Pedicel length & $1-11$ & $3-14$ & $6-17$ & $6-19$ & $\ldots$ & $\ldots$ \\
\hline
\end{tabular}

${ }^{\mathrm{x}}$ At each location, leaf samples were collected from multiple fields. For each sample, 50 spores from each of four leaves were measured, and a range of dimensions was determined for each location. The following number of fields was sampled: Soledad, three fields; King City, four fields; Hollister, two fields; Bakersfield, two fields; Salinas (onion), one field.

${ }^{\mathrm{y}}$ For the onion sample, only uredia were observed.

${ }^{\mathrm{z}}$ Published values are from Laundon and Waterston (23).

Table 3. Allium host range of garlic rust (Puccinia allii) isolates from California

\begin{tabular}{|c|c|c|c|c|}
\hline \multirow{2}{*}{$\begin{array}{l}\text { Inoculated } \\
\text { plant }\end{array}$} & \multirow[b]{2}{*}{ Cultivar $^{y}$} & \multicolumn{3}{|c|}{ Disease severity ${ }^{z}$} \\
\hline & & Soledad & King City & Hollister \\
\hline \multirow[t]{2}{*}{ Garlic } & California Late & 1.9 & 1.8 & 1.3 \\
\hline & Chinese Early Red & 1.8 & 1.8 & 1.4 \\
\hline \multirow[t]{4}{*}{ Onion } & Yula & 1.0 & 1.0 & 1.0 \\
\hline & Southport White & 1.0 & 1.0 & 1.0 \\
\hline & Stockton Early Yellow & 1.2 & 1.0 & 1.2 \\
\hline & Early Red Burger & 1.0 & 1.2 & 1.0 \\
\hline Chives & Fine Leaved & 1.0 & 1.0 & 1.0 \\
\hline \multirow[t]{3}{*}{ Leek } & Titan & 0 & 0 & 0 \\
\hline & Broad London & 0 & 0 & 0 \\
\hline & Gavilan & 0 & 0 & 0 \\
\hline Elephant garlic & na & 0 & 0 & 0 \\
\hline \multirow[t]{3}{*}{ Shallot } & Ambition & 0 & 0 & $\mathrm{nt}$ \\
\hline & Atlas & 0.1 & 0.1 & $\mathrm{nt}$ \\
\hline & Creation & 0 & 0 & $\mathrm{nt}$ \\
\hline $\operatorname{LSD}(P=0.05)$ & & 0.20 & 0.21 & 0.17 \\
\hline
\end{tabular}

${ }^{\mathrm{x}}$ All plants were at least 2 months old when spray inoculated with spore suspensions ( $10^{7}$ urediniospores per $\mathrm{ml}$ ). Plants were then incubated in a dew chamber for $48 \mathrm{~h}$ and subsequently maintained in a greenhouse $\left(22\right.$ to $\left.24^{\circ} \mathrm{C}\right)$.

${ }^{\mathrm{y}}$ na $=$ not applicable.

${ }^{\mathrm{z}}$ Rust inoculum was collected from fields in three locations: Soledad, King City, and Hollister. Plants were evaluated after 4 weeks for disease severity using a rust severity scale where $0=0 \%, 1$ $=1$ to $10 \%, 2=11$ to $25 \%, 3=26$ to $50 \%, 4=51$ to $75 \%$, and $5=76$ to $100 \%$ of the leaf surface was covered with lesions. Severity values presented are the means of 10 plants. Inoculations were carried out two times, and results for the two tests were similar. nt $=$ not tested. 
leaves and greater yields except for the low-rate mancozeb and benzothiadiazole treatments. Most tebuconazole and azoxystrobin treatments, at either 10- or 20-day intervals and low or high rates, resulted in significantly greater percent soluble solids.

Cultivar evaluation. There were clear differences among the cultivars in rust severity on the third, fourth, and fifth leaves, as well as for the total number of viable leaves per plant (data not shown). Included in the trial were early-, middle-, and late-season cultivars $(11,11$, and 12 cultivars, respectively). These maturity groups did not differ in disease resistance as indicated by severity ratings on the third, fourth, and fifth leaves. For example, the mean group ratings for the fifth leaf were 3.5 (early), 3.3 (middle), and 3.4 (late). Cultivars that possessed the greatest tolerance to garlic rust, as measured by disease severity on the fourth and fifth leaves, were W6-8413, W6-2308, W68418, and PI-540380. Other cultivars showed intermediate tolerance or were highly susceptible. Significant differences existed among cultivars when the number of total viable leaves was considered, although no differences were found among maturity groups. However, the total number of leaves produced and the number of viable leaves at any given growth stage varied among cultivars (24).

\section{DISCUSSION}

Although garlic rust may have been found in California as early as 1934 and was briefly mentioned in a 1940 note (14), to our knowledge this present report is the first to characterize garlic rust in California and to identify the pathogen as $P$. allii.
There are several rust pathogens that infect commercial Allium crops and can be separated by teliospore and telium morphology $(16,19,23,32,33)$. $P$. allii is characterized by two-celled teliospores and telia containing groups of fused paraphyses. Puccinia porri (Sow.) Wint. has teliospores that are both one- and two-celled and telia without paraphyses. Puccinia mixta Fuckel is considered to be a synonym of $P$. porri. Uromyces ambiguous (DC.) Lév has onecelled teliospores and nonparaphysate telia. All California isolates had two-celled teliospores and paraphysate telia and were therefore identified as $P$. allii.

Rust on garlic appears to be distributed worldwide, including Europe (France, The Netherlands), Australasia (Australia, New Zealand, India), the Middle East (Israel, Egypt), Africa (South Africa, Tanzania), South America (Brazil, Chile), and North America (United States) $(12,25,27,30)$. In the United States, garlic rust apparently has been reported only in the states of Cali- fornia $(12,14)$ and Oregon (J. Griesbach, personal communication). In the intervening years between the 1940 occurrence and the devastating 1998 outbreak, the extent of rust incidence and severity in the state is not known. Long-time growers of garlic in coastal California were interviewed in 1998 and 1999 and were not sure rust ever had been observed in their area, although researchers and field personnel have seen this disease on occasion in the San Joaquin Valley. With the exception of 1940 and 1941 notations $(14,34)$, no official records documented garlic rust in California until the 1998 season, providing further indications that this disease may be of sporadic occurrence in California. Prior to 1998, economic damage from garlic rust was not documented.

$P$. allii has been found to infect 20 different species in the genus Allium, including a wide range of commercial Allium crops such as chives, garlic, Japanese bunching or Welsh onion (A. fistulosum),

Table 5. Efficacy of fungicides tested in Kern County (1998C)

\begin{tabular}{lccc}
\hline Treatment, rate/ha & $\begin{array}{c}\text { \% Leaf area } \\
\text { diseased }\end{array}$ & $\begin{array}{c}\text { Foliage dry } \\
\text { weight }(\mathbf{k g})^{\mathbf{y}}\end{array}$ & $\begin{array}{c}\text { Mean bulb } \\
\text { weight }(\mathbf{g})^{\mathbf{z}}\end{array}$ \\
\hline Metalaxyl-mancozeb, $2.80 \mathrm{~kg}$ & 1.8 & 0.48 & 30.4 \\
Chlorothalonil, $2.50 \mathrm{~kg}$ & 2.2 & 0.54 & 28.4 \\
Sulfur, $11.20 \mathrm{~kg}$ & 3.1 & 0.45 & 28.9 \\
Copper hydroxide, $1.40 \mathrm{~kg}$ & 3.9 & 0.40 & 27.8 \\
Maneb, 2.70 kg & 1.9 & 0.52 & 25.5 \\
Control & 3.2 & 0.45 & 25.5 \\
LSD $(P=0.10)$ & 1.3 & 0.08 & 3.1 \\
\hline
\end{tabular}

${ }^{y}$ Fifteen of the youngest leaves per plot were randomly sampled and rated for percent leaf surface covered with lesions. Leaves were then oven-dried at $45^{\circ} \mathrm{C}$ for 7 days and the resulting dry weights recorded.

${ }^{\mathrm{z}}$ Garlic bulbs were harvested from a 1-m row in the center bed of each plot, trimmed, and weighed. Mean bulb weight was then calculated.

Table 4. Efficacy of fungicides tested in San Benito County (1998A and 1998B)

\begin{tabular}{|c|c|c|c|c|c|c|}
\hline \multirow[b]{2}{*}{ Treatment, rate/ha } & \multicolumn{3}{|c|}{ Disease severity $^{w}$} & \multirow{2}{*}{$\begin{array}{l}\text { Total viable } \\
\text { leaves }^{x}\end{array}$} & \multirow{2}{*}{$\begin{array}{l}\text { Yield } \\
(\mathbf{k g} / \mathbf{h a})\end{array}$} & \multirow[b]{2}{*}{$\%$ Soluble solids ${ }^{\mathrm{z}}$} \\
\hline & 3rd leaf & 4th leaf & 5th leaf & & & \\
\hline \multicolumn{7}{|l|}{$1998 \mathrm{~A}$} \\
\hline Propiconazole, 0.59 liter & 0.3 & 0.5 & 0.7 & 6.3 & 11,208 & 28.1 \\
\hline Myclobutanil, $0.28 \mathrm{~kg}$ & 1.1 & 1.7 & 2.4 & 5.1 & 7,397 & 26.3 \\
\hline Azoxystrobin, 1.13 liter & 0.2 & 0.1 & 0.3 & 6.9 & 17,485 & 29.2 \\
\hline Chlorothalonil, 2.34 liter & 1.6 & 2.6 & 3.1 & 5.0 & 6,277 & 25.2 \\
\hline Iprodione, 1.75 liter & 2.1 & 2.9 & 3.4 & 5.1 & 5,380 & 25.5 \\
\hline Tebuconazole, 0.59 liter & 0.0 & 0.1 & 0.1 & 7.4 & 17,933 & 29.4 \\
\hline Maneb, $3.37 \mathrm{~kg}$ & 1.4 & 2.2 & 3.4 & 5.2 & 6,501 & 25.3 \\
\hline Control & 2.1 & 3.1 & 3.8 & 4.8 & 4,932 & 25.7 \\
\hline $\operatorname{LSD}(P=0.05)$ & 0.5 & 0.4 & 0.7 & 0.5 & 2,690 & 1.6 \\
\hline \multicolumn{7}{|l|}{ 1998B } \\
\hline Mancozeb, $3.37 \mathrm{~kg}$ & 0.8 & 1.8 & 3.2 & 6.4 & 4,259 & 36.6 \\
\hline Tebuconazole, 0.59 liter & 0.1 & 0.1 & 0.5 & 7.1 & 7,846 & 39.7 \\
\hline Azoxystrobin, 1.13 liter & 0.1 & 0.5 & 0.7 & 7.0 & 7,173 & 38.8 \\
\hline Chlorothalonil, 2.34 liter & 1.0 & 1.9 & 3.0 & 6.3 & 3,587 & 36.8 \\
\hline $\begin{array}{l}\text { Chlorothalonil, } 2.34 \text { liter + } \\
\text { Manzate, } 3.37 \mathrm{~kg}\end{array}$ & 0.7 & 1.6 & 2.8 & 6.4 & 4,932 & 37.4 \\
\hline Control & 1.3 & 2.8 & 3.8 & 5.8 & 3,138 & 34.2 \\
\hline $\operatorname{LSD}(P=0.05)$ & 0.2 & 0.5 & 0.6 & 0.5 & 1,569 & 1.4 \\
\hline
\end{tabular}

${ }^{\text {w }}$ Disease severity was rated on 23 April (1998A, Chinese Early Red garlic) and 30 April (1998B, California Late garlic) using a rust severity scale where $0=0 \%, 1=1$ to $10 \%, 2=11$ to $25 \%, 3=26$ to $50 \%, 4=51$ to $75 \%$, and $5=76$ to $100 \%$ of the leaf surface was covered with lesions.

${ }^{x}$ The total number of viable leaves per plant (viable $=$ more than $75 \%$ of the leaf area was healthy) was counted. Eight plants were evaluated per plot and a mean value was derived.

${ }^{y}$ Plot yields were determined by harvesting $10 \mathrm{ft}$ of garlic from the middle two rows of the plots. Harvested bulbs were trimmed according to standard commercial practice and weighed.

${ }^{\mathrm{z}}$ Percent soluble solids was determined for 20 cloves per plot with a temperature compensating refractometer. 
leek, onion, and shallot $(3,8,12,29)$. Wild species of Allium such as A. carinatum, $A$. roseum, and $A$. sphaerocephalon are also susceptible (3). The wild plant Nectaroscordum siculum appears to be the only reported non-Allium host of $P$. allii (3).

In inoculation experiments, our garlic rust isolates infected garlic, onion, and chives, but were consistently unable to cause disease in leek, elephant garlic, and shallot. This inability to infect leek is notable because in Europe, $P$. allii is extremely damaging to leek $(7,9,11,20,31)$. Morphologically, the California garlic isolates match the descriptions of leek isolates from Europe; hence, there is strong evidence for the existence of distinct strains with different host ranges. Other researchers have noted similar evidence. Onion fields that were adjacent to rust-infected garlic in California in 1934 and 1940 did not develop the disease (14), while in the 1941 report (34), a garlic rust isolate was able to infect onion in inoculation studies. In Japan, Welsh onion may develop rust, but other nearby onion crops either do not develop disease or have significantly lower disease severity (15). Some isolates from leek appear unable to cause disease on onion and chives (18). It would be interesting to analyze various $P$. allii strains on a molecular level and to compare possible differences with host range data.

Surveys for rust disease were conducted in commercial Allium plantings that were near or adjacent to diseased garlic fields. In 1998 and 1999, several onion fields growing in close proximity to diseased garlic developed rust disease. However, the few leek fields found near diseased garlic plantings were free from rust. In 2000, a shallot field was symptomless even though it was adjacent to a severely infected garlic field. These survey findings were consistent with our greenhouse studies that showed California isolates from garlic can infect onion but not leek or shallot.

The inability of $P$. allii to infect leek and elephant garlic is interesting because these two crops are closely related and are in different Groups of the Allium ampeloprasum species. However, onion and shallot are likewise closely related, being members of different Groups of Allium cepa species. Onions are clearly susceptible to $P$. allii, while shallots have a high degree of resistance. Thus, the resistancesusceptibility to this disease crosses the lines of Allium subgenera, species, and subspecies (26).

Epidemiological details of the California garlic rust outbreak are lacking. The original source of inoculum is unknown. The fungus may always be present at extremely low levels, although this has not been documented. Our garlic seed greenhouse study showed that cloves developing from diseased plants that were covered with urediniospores and teliospores did not develop rust, calling into question the importance of infested cloves. However, additional studies would be needed to further explore this aspect.

It is also not known how the pathogen survives between garlic crops. In the California garlic production system, there is a gap from late July to early October when there is no garlic present in the field. However, onion and chives present during this gap could possibly be infected with low, undetected levels of rust. In addition, noncommercial or wild Allium species growing throughout the state could possibly harbor the pathogen, similar to the occurrence of $P$. allii on noncommercial Alliums in the U.K. (3). Therefore, there is a possible "green bridge" (21) that enables the pathogen to survive until the next garlic crop; such a bridge is important for the development of leek rust in Europe, presumably because the urediniospore stage is the main spore stage present and other stages are rarely found $(9,10,18)$. Now that rust has occurred in coastal garlic fields at significant levels for three consecutive years, it appears possible that the abundant development of teliospores may be a mechanism for pathogen survival between garlic crops.

In the fungicide trials, both tebuconazole (Folicur 3.6F) and azoxystrobin (Quadris 2.08SC) consistently provided the best control of rust and the highest garlic yields. In four trials, tebuconazole treatments resulted in yield increases of 1.6, 2.0, 2.5, and 3.6 times those of untreated controls. In Europe and Brazil, mancozeb and propiconazole have been used for garlic rust control $(1,2,4,13,27)$. Experiments in France have also found tebuconazole to be effective on garlic rust (5). Tebuconazole has a Section 18 registration (emergency exemption) for garlic in California. At both 1998 sites, all yields, even those of the best

Table 6. Efficacy of fungicides tested in Monterey County, combined over two locations (1999A and 1999B)

\begin{tabular}{|c|c|c|c|c|c|c|}
\hline \multirow[b]{2}{*}{ Treatment, rate/ha, interval } & \multicolumn{3}{|c|}{ Disease severity $^{v}$} & \multirow{2}{*}{$\begin{array}{c}\text { Total viable } \\
\text { leaves }^{w}\end{array}$} & \multirow{2}{*}{$\begin{array}{c}\text { Yield }^{x} \\
\text { (kg/ha) }\end{array}$} & \multirow[b]{2}{*}{ \% Soluble solids ${ }^{y}$} \\
\hline & 3rd leaf & 4th leaf & 5th leaf & & & \\
\hline \multicolumn{7}{|l|}{ 1999A and B combined } \\
\hline Tebuconazole, 0.59 liter, 10 days & 1.2 & 1.6 & 1.8 & 8.1 & 30,352 & 36.4 \\
\hline Tebuconazole, 0.59 liter, 20 days & 1.9 & 2.9 & 3.9 & 6.5 & 28,491 & 35.6 \\
\hline Tebuconazole, 0.44 liter, 10 days & 1.0 & 1.4 & 1.5 & 8.0 & 31,024 & 37.3 \\
\hline Tebuconazole, 0.44 liter, 20 days & 1.8 & 2.8 & 3.8 & 5.9 & 23,201 & 35.8 \\
\hline Azoxystrobin, 1.13 liter, 10 days & 0.9 & 1.4 & 1.6 & 8.2 & 27,259 & 36.3 \\
\hline Azoxystrobin, 1.13 liter, 20 days & 1.7 & 2.7 & 3.4 & 6.7 & 27,662 & 36.8 \\
\hline Azoxystrobin, 0.80 liter, 10 days & 1.0 & 1.5 & 1.9 & 7.7 & 24,120 & 36.9 \\
\hline Azoxystrobin, 0.80 liter, 20 days & 1.6 & 2.6 & 3.6 & 6.2 & 26,115 & 36.6 \\
\hline Mancozeb, $3.37 \mathrm{~kg}, 10$ days & 1.7 & 2.8 & 3.6 & 5.5 & 22,506 & 34.9 \\
\hline Mancozeb, $3.37 \mathrm{~kg}, 20$ days & 2.0 & 3.4 & 4.4 & 4.3 & 22,148 & 34.3 \\
\hline Benzothiadiazole, $0.07 \mathrm{~kg}, 10$ days & 2.1 & 3.2 & 4.2 & 4.4 & 19,839 & 35.2 \\
\hline Control & 2.0 & 3.1 & 4.2 & 4.4 & 16,924 & 34.9 \\
\hline $\operatorname{LSD}(P=0.05)$ & 0.4 & 0.5 & 0.6 & 0.8 & 5,470 & 1.4 \\
\hline Contrast & \multicolumn{6}{|c|}{ Significance of $F^{z}$} \\
\hline Fungicide vs. control & $* *$ & $* * *$ & $* * *$ & $* * *$ & $* * *$ & $*$ \\
\hline Teb. \& azo. vs. man. \& ben. & $* * *$ & $* * *$ & $* * *$ & $* * *$ & $* * *$ & $* * *$ \\
\hline \multicolumn{7}{|l|}{ Teb. \& azo. } \\
\hline Interval & $* * *$ & $* * *$ & $* * *$ & $* * *$ & ns & ns \\
\hline Rate & ns & ns & ns & $*$ & ns & ns \\
\hline Teb. vs. azo. & $\mathrm{ns}$ & $\mathrm{ns}$ & ns & $\mathrm{ns}$ & $\mathrm{ns}$ & $\mathrm{ns}$ \\
\hline
\end{tabular}

${ }^{\mathrm{v}}$ Disease severity was rated on 13 May (1999A, California Early Red garlic) and 25 May (1999B, California Early garlic) using a rust severity scale where $0=0 \%, 1=1$ to $10 \%, 2=11$ to $25 \%, 3=26$ to $50 \%, 4=51$ to $75 \%$, and $5=76$ to $100 \%$ of the leaf surface covered with lesions.

${ }^{\mathrm{w}}$ Total number of viable leaves per plant (viable $=$ more than $75 \%$ of leaf area was healthy) was counted. Eight plants were evaluated per plot and a mean value was derived.

x Plot yields were determined by harvesting $10 \mathrm{ft}$ of garlic from the middle two rows of the plots. Harvested bulbs were trimmed according to standard commercial practice and weighed.

y Percent soluble solids was determined for 20 cloves per plot with a temperature compensating refractometer.

${ }^{\mathrm{z}}$ For significance of $F, \mathrm{~ns}=$ not significant, ${ }^{*}=$ significant at $P=0.05, * *=$ significant at $P=0.01, * * *$ significant at $P=0.001$. 
treatments, were significantly lower than expected for commercial production. This depression most likely occurred because the trial was initiated after rust had become well established in all the experimental plots, and it illustrates the need to deploy the fungicides as protectants.

With the availability of tebuconazole, commercial garlic was sufficiently protected during the 1999 and 2000 seasons, and yields were normal. To determine whether the garlic rust pathogen could cause significant damage in a year in which wet and cool El Niño weather conditions did not exist, we arranged for some growers in coastal California in 1999 and 2000 to omit Folicur applications in large experimental plots in commercial fields. Interestingly, in these plots the rust was as severe as the disease during the El Niño year, and yields from these plots were likewise severely reduced (Fig. 1). However, in the interior San Joaquin Valley, where many garlic fields did not receive Folicur treatments in 1999 and 2000, rust failed to develop to serious levels. This indicates that an important environmental component is involved with the epidemiology of garlic rust in the various parts of California. It appears that garlic rust has become more common in coastal regions of the state and, without fungicide controls or resistant cultivars, the disease may severely limit garlic production in those areas.

Total number of viable leaves was an excellent measure of disease severity for fungicide trials where one variety was planted; however, natural variability in leaf number among varieties made this parameter less useful in the cultivar evaluation experiment. Variability of Allium species and garlic varieties to garlic rust is encouraging, although none of the varieties evaluated possessed high degrees of resistance. The varieties that possessed the
A

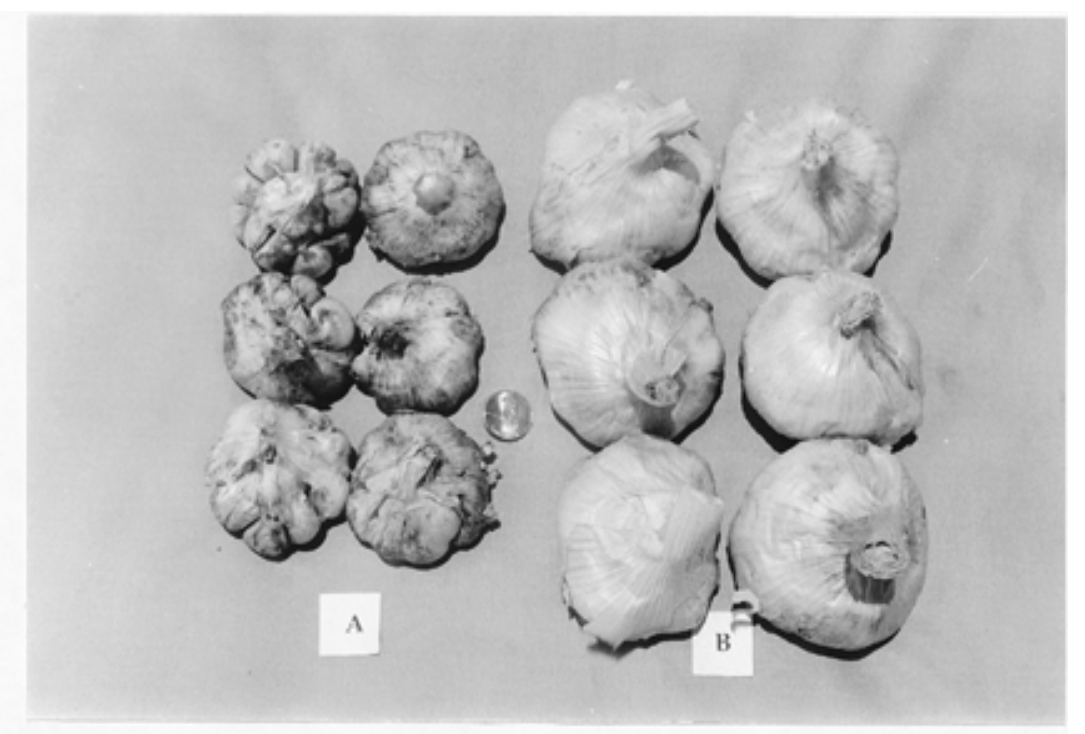

B

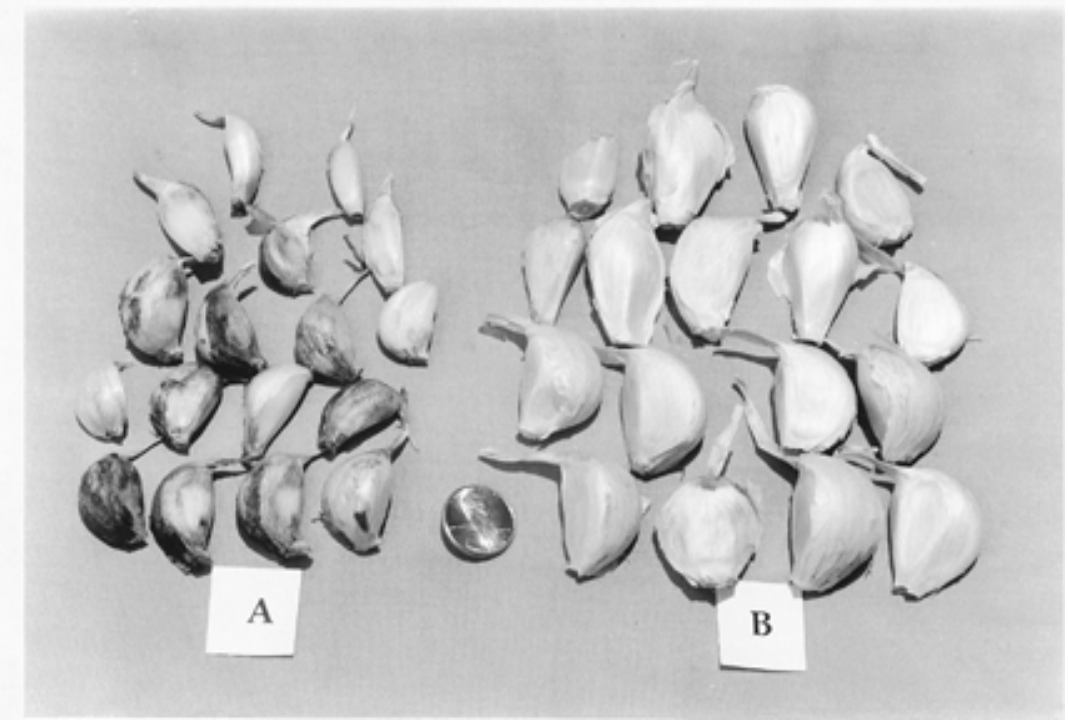

Fig. 1. Effects of severe rust disease on commercially grown garlic bulbs and cloves. A, Bulbs harvested from untreated (A) and tebuconazole (0.59 liter/ha) treated (B) plants. B, Cloves from untreated (A) and tebuconazole ( 0.59 liter/ha) treated (B) plants. greatest tolerance to garlic rust are not commercially available in the United States. Because $P$. allii may have become established California, effective fungicide treatments will be needed in some regions until resistant cultivars are developed.

\section{ACKNOWLEDGMENTS}

We acknowledge the support of the American Dehydrated Onion \& Garlic Association and assistance from Basic Vegetables, Christopher Ranch, Empire Research, Gilroy Foods, Rogers Foods, Western Farm Service, and technicians Steve Boutry, Teo Gonzales, Luis Guerrero, David Haviland, Patrick Headley, Diana Henderson, Devin Kile, David Miltz, and Kevin Simonin. We thank Hartnell College for the use of their East Campus facility. We thank the following for their help and interest in this project: Carol Adams, Mike Brautovich, Kevin Brink, Fred Crowe, Bob Ehn, Mike Hardoy, Kris Headley, Kathy Kosta, Ed Kurtz, Mac Learned, Mike Mantelli, Steve Moss,

Herb Phillips, Gail Pierleoni, Jerry Rava, Heather Scheck, Dora Tabancay, Tim Tidwell, Rick Yraceburu, and Murilo Zerbini.

\section{LITERATURE CITED}

1. Aguilar, J. A. E., and Reifschneider, F. J. B. 1986. Efficiency of fungicides on the control of garlic rust. Hortic. Bras. 4:26-28.

2. Aguilar, J. A. E., Reifschneider, F. J. B., and Cordeiro, C. M. T. 1986. Effects of spreaderstickers on the control of garlic rust. Fitopatol. Bras. 11:237-240.

3. Beckett, A., Houston, L., and Frost, L. C. 1992. New host records for Puccinia allii Rud. Plant Pathol. 41:83-85.

4. Blum, L. E. B., and Gabardo, H. 1993 Chemical control of the garlic rust in Curitibanos/SC, Brazil. Fitopatol. Bras. 18:230232.

5. Burgaret, Y., Sauris, P., and Marin, H. 1996 White rot and rust of garlic: Mastering chemical control, it is possible! Phytoma 487:45-47.

6. California Agricultural Statistics Service. 1997, 1998, and 1999 County Agricultural Commissioners' Data. Calif. Agric. Stat. Serv.

7. Clarkson, J. P., Kennedy, R., Phelps, K. Davies, J., and Bowtell, J. 1997. Quantifying the effect of reduced doses of propiconazole (Tilt) and initial disease incidence on leek rust development. Plant Pathol. 46:952-963.

8. Dale, W. T. 1970. Aecidia of Puccinia allii Rud. on chives in Britain. Plant Pathol. 19:149.

9. de Jong, P. D. 1995. Growth of leek rust epidemics in time in three cultivars during the early stage of the epidemic. Eur. J. Plant Pathol. 101:139-148.

10. de Jong, P. D., Daamen, R. A., and Rabbinge, R. 1995. The reduction of chemical control of leek rust, a simulation study. Eur. J. Plant Pathol. 101:687-693.

11. de Jong, P. D., and de Bree, J. 1995. Analysis of the spatial distribution of rust-infected leek plants with the black-white join-count statistic. Eur. J. Plant Pathol. 101:133-137.

12. Farr, D. F., Bills, G. F., Chamuris, G. P., and Rossman, A. Y. 1989. Fungi on Plants and Plant Products in the United States. American Phytopathological Society, St. Paul, MN.

13. Garcia, D. C., Barni, V., and Dettmann, L. A. 1994. Fungicides on the control of garlic rust. Ciencia Rural, Santa Maria 24:25-28.

14. Gardner, M. W. 1940. Garlic rust in California. Plant Dis. Rep. 24:298-299.

15. Goto, K. 1933. Onion rusts of Japan, I. J. Soc. Trop. Agric. 2:167-177.

16. Harrison, J. M. 1987. Observations on the occurrence of telia of Puccinia porri on leeks in the U. K. Plant Pathol. 36:114-115.

17. Jennings, D. M., Ford-Lloyd, B. V., and But- 
ler, G. M. 1989. An aniline blue squash technique for observation of urediospore germ pores. Mycol. Res. 92:230-232.

18. Jennings, D. M., Ford-Lloyd, B. V., and Butler, G. M. 1990. Rust infections of some Allium species: An assessment of germplasm for utilizable rust resistance. Euphytica 49:99109.

19. Jennings, D. M., Ford-Lloyd, B. V., and Butler, G. M. 1990. Morphological analysis of spores from different Allium rust populations. Mycol. Res. 94:83-93.

20. Jennings, D. M., Ford-Lloyd, B. V., and Butler, G. M. 1990. Effect of plant age, leaf position, and leaf segment on infection of leek by leek rust, Puccinia allii. Plant Pathol. 39:591597.

21. Jones, O. W. 1985. Comparison of fungicides for control of rust on leeks, 1980-1982. Tests of Agrochemicals and Cultivars. Ann. Appl. Biol. (Suppl.) 106:52-53.

22. Koike, S. T., Smith, R. F., Davis, R. M., and Nunez, J. J. 1999. Severe outbreak of garlic rust disease in California. Pages 241-243 in: Proc. 1998 Natl. Onion (and other Allium) Res. Conf., Sacramento, CA.

23. Laundon, G. F., and Waterston, J. M. 1965. Puccinia allii. C.M.I. Descriptions of Pathogenic Fungi and Bacteria No. 52. Commonw. Mycol. Inst.

24. Mann, L. K., and Minges, P. A. 1958. Growth and bulbing of garlic (Allium sativum L.) in response to storage temperatures of planting stocks, daylength and planting date. Hilgardia 27(15):385-390

25. Parmelee, J. A. 1973. Puccinia allii on garlic, an interception. Can. Plant Dis. Surv. 53:147149.

26. Rabinowitch, H. D., and Brewster, J. L. 1990. Onions and Allied Crops. Vol. I. Botany, Physiology and Genetics. CRC Press, Inc., Boca Raton, FL.

27. Rochecouste, J. F. G. 1984. Chemical control of garlic rust. Australas. Plant Pathol. 13:4748.

28. Schwartz, H. F., and Mohan, S. K., eds. 1995.
Compendium of Onion and Garlic Diseases. American Phytopathological Society, St. Paul, $\mathrm{MN}$.

29. Sherf, A. F., and MacNab, A. A. 1986. Vegetable Diseases and Their Control. 2nd ed John Wiley \& Sons, New York.

30. Singh, B. M., and Sharma, Y. R. 1977. Rust on garlic. FAO Plant Prot. Bull. 25:41-42.

31. Smith, B. M., and Crowther, T. C. 1992. Field assessment of the reaction of leek cultivars to leek rust. Tests of Agrochemicals and Cultivars 13:104-105. In Ann. Appl. Biol. 120 (Suppl.).

32. Uma, N. U., and Taylor, G. S. 1986. Occurrence and morphology of teliospores of $\mathrm{Puc}$ cinia allii on leek in England. Trans. Br. Mycol. Soc. 87:320-323

33. Wilson, M., and Henderson, D. M. 1966. British Rust Fungi. Cambridge University Press, Cambridge, UK.

34. Yarwood, C. E., and Gardner, M. W. 1941. Garlic rust infects onion. Plant Dis. Rep. 25:202. 